\title{
Garbage Collecting Ship Robot Using Arduino Uno Microcontroller Based on Android Smartphone
}

\author{
Yuda Irawan ${ }^{1}$, Hendry Fonda ${ }^{2}$, Yulisman $^{3}$, Mardeni $^{4}$ \\ 1,2,3 Department of Information System, STMIK Hang Tuah Pekanbaru, Pekanbaru, Indonesia \\ ${ }^{4}$ Department of Computer Science, STMIK Hang Tuah Pekanbaru, Pekanbaru, Indonesia \\ 1yudairawan89@gmail.com*, ${ }^{2}$ fondaanda@gmail.com, ${ }^{3}$ yulisman@htp.ac.id
}

\begin{abstract}
Garbage collection in the Siak tributary used an excavator where the excavator cannot reach the garbage in the middle of the Siak tributary. To make it easier to collect garbage in the middle of the Siak tributary, a robotic ship collecting robot system is make using: ardino uno microcontroller with joystick controller ps 2 based on an android smartphone. The whole tool was divided into several parts, which consist of an Android smartphone, PS 2 wireless receiver, Arduino Uno microcontroller, PS 2 joystick, motor relay driver, DC motor, servo motor, and camera. This tool works when the PS 2 Joystick connects the connection to the PS 2 wireless receiver, and the PS 2 wireless receiver then to the Arduino Uno microcontroller to process commands, from the Arduino Uno microcontroller then to the motor relay driver that works to regulate the voltage of the electric current to drive the DC motor, and Servo motors function to transport trash in the river, as well as smartphones as displays to display the results of the camera. The method used is the prototype method. The results showed that the PS 2 joystick could communicate with Arduino Uno with a distance of 25 meters if there is no barrier and 15 meters if there is a barrier and the robot ship is only in the form of a prototype that is only able to take out garbage such as drink bottles caps, caps galon, and drink glass 200 gram.
\end{abstract}

Keywords - Arduino Uno Microcontroller, Prototype, ps 2 Joystick, Ps 2, Android Smartphone, Garbage Collection.

\section{INTRODUCTION}

Industrial development and population growth, which are increasing from year to year, increase industrial waste and domestic waste generated by the population so that it increasingly burdens the land, air, and rivers that flow in urban areas[1]-[6]. As a result of the increase in population, which annually has increased waste[7]-[12].

Garbage is a form of problem that is often faced by people in the world [13]-[20]. Garbage has two types, namely organic (wet) and inorganic (dry) waste[21]-[24]. The types of waste that are mostly found floating in rivers are organic and inorganic waste [25]-[30]. The form of organic waste is waste that easily decomposes naturally, while the form of inorganic waste is the opposite of non- rotting organic waste or commonly called dry waste[31][36]. Garbage that is continuously dumped in the river causes flooding when it rains with high rainfall and water pollution in the river, which will harm the residents living around the tributary of the Siak river because some residents will use the water for household needs[37]-[40]. Waste data from 2017 to 2019 can be seen in Table 1:

Table 1. Waste data from 2017 - 2019

\begin{tabular}{|c|c|c|}
\hline Year & $\begin{array}{c}\text { Garbage in } \\
\text { the River } \\
\text { (Tons / Day) }\end{array}$ & $\begin{array}{c}\text { Amount of } \\
\text { Garbage (Tonnes / } \\
\text { Month) }\end{array}$ \\
\hline 2017 & 15.180 & 182.160 \\
\hline 2018 & 17.608 & 211.296 \\
\hline 2019 & 21.129 & 253.548 \\
\hline
\end{tabular}

Source: Pekanbaru City Environment and Sanitation Office 2019

Based on data from the Environmental and Cleanliness Service of Pekanbaru City from 2017 to 2019, garbage in the rivers has increased every year, the most waste floating in the river such as drink bottles, bottle caps, shampoo bottles, and other plastic waste[41]-[48]. Garbage collection using an excavator in the river is carried out by cleaning officers in one week twice[49]-[50].

To clean the river from floating rubbish, cleaners usually use an excavator machine. This machine works by picking up trash that is on the edge of the Siak River, which is directly controlled by the cleaning service. In the process of picking up floating garbage on the Siak tributary, the excavator machine has difficulty picking up garbage in the middle of the Siak tributary because the Siak tributary is 10 meters wide while the excavator's reach is only 3.5 meters from the edge of the Siak tributary. The types of waste that are mostly found in the middle of the Siak river are bottle waste and plastic waste. To pick up garbage in the middle of the Siak tributary that cannot be reached by the excavator, the janitor pushes the trash to the excavator so that it can be reached and picked up by the excavator. Therefore, this ship robot is expected to be able to help excavators in collecting garbage in the middle of river waters with a river width of 10 meters and picking up trash such as drink bottles, bottle caps, and plastic waste. 
This problem can be overcome by utilizing existing technology, one of which is the use of joysticks and smartphones or so-called smartphones based on the Android operating system and the Arduino Uno microcontroller[10]. This study uses the garbage collection method in the river with a joystick PS 2 as a controller for the trash collecting ship robot in the Siak River and an Android smartphone as a display to display the results of the mini camera and Arduino Uno as hardware for the input/output system process and wireless PS 2 as a connector[11]. Between Joystick ps 2 and Arduino Uno. In accordance with technological developments, there is a need for a system that can assist in collecting river waste and can make it easier for cleaners to collect garbage in the river and facilitate the control process that can make cleaning personnel efficient[12].

\section{METHODOLOGY}

In this stage, the researcher uses the prototype method because this method is a method that is widely used by software developers[13]. The essence of this method is the work of a model development into a final system[14]-[51][52].

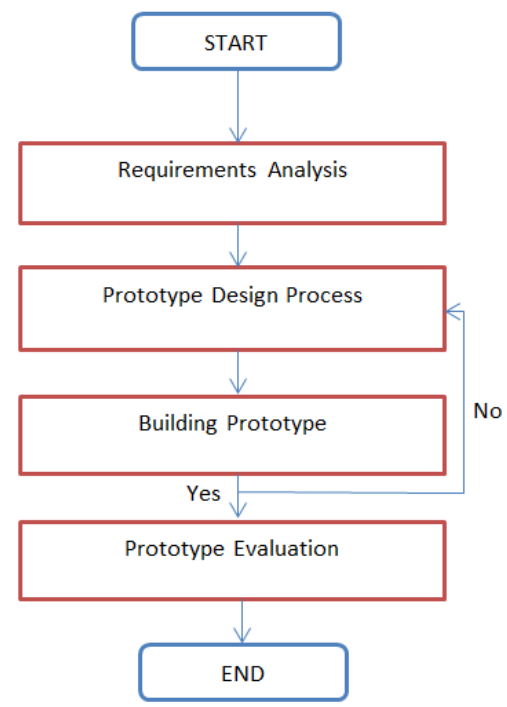

Fig.1. Prototype Model Stages

The following are the stages of developing a prototype model:

\section{a. Collection of Needs}

Collection of Requirements is the stage where the client and developer jointly define the software and identify needs and systems that are created in consultation with the Pekanbaru City Environmental and Sanitation Office[15][53].

\section{b. Prototype Design Process}

At this stage of the design process, the authors plan and design the design before carrying out the tool-making process[54].

\section{c. Building Prototype}

In this stage, the writer builds a prototype while designing a temporary design that focuses on making tools.

\section{d. Prototype Evaluation}

In the Prototyping Evaluation Phase, the results of the software design will be realized to the cleaning officers of the Pekanbaru City Environment and Sanitation Service, whether the prototyping that is built is in accordance with the wishes and needs of the janitor or not. If it does not match, the prototyping will be revised by repeating the previous steps[16],[17].

\section{RESULTS AND DISCUSSION \\ Process Analysis}

Process analysis is to analyze the process from the first time the PS 2 system and joystick as controllers are built and until the PS 2 joystick can control the garbage collection ship robot in the river. In making a trash pick-up ship robot in the river using an Arduino Uno microcontroller with an Android smartphone-based PS 2 joystick controller, this is done in stages:

1. The vessel is made of acrylic coated with paralon pipes.

2. The ship measures $21.0 \times 2.97$ centimeters.

3. Connect the PS 2 wireless receiver device to the Arduino Uno R3, which functions as a link between the PS 2 joystick and the Arduino Uno

4. Connect the Arduino Uno R3 to the motor relay driver, which functions to regulate the voltage of the electric current, and the DC motor functions to mobilize the ship robot.

5. Connecting Arduino Uno R3 to a servo motor which functions to lift trash into the ship robot

6. Joystick PS 2 as a controller for the garbage collecting ship robot in the river by controlling motion with forwarding, backward, left, and right commands

7. Smartphone as a display to display the results of a camera that is connected via a wireless camera.

System Configuration Analysis

The following is a description of the configuration of a garbage collection ship robot using an Arduino Uno microcontroller with an Android smartphone-based PS 2 joystick controller on the river. The image below is a series of tools for the Waste Collection Ship Robot System Using the Arduino Uno Microcontroller with an Android Smartphone-Based Joystick Controller for Ps 2. 


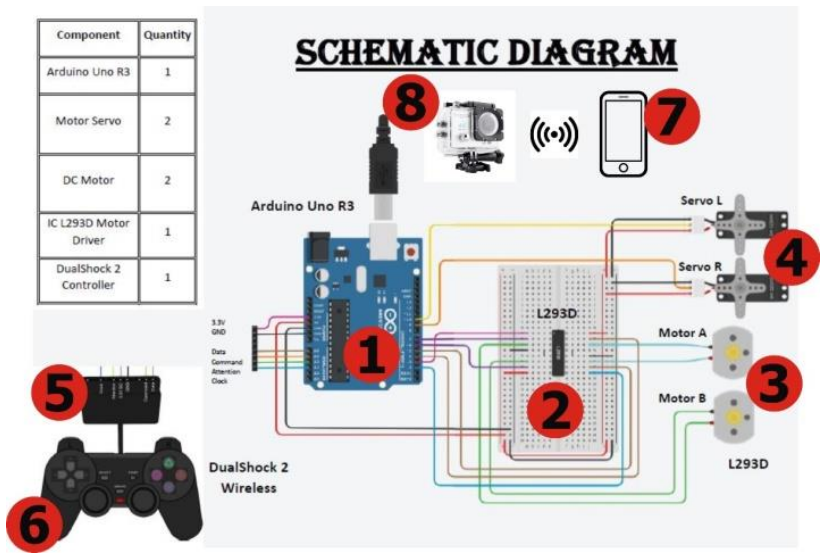

Fig.2. Overall Hardware Configuration Series

From Figure 2, it can be explained as follows:

1. Arduino Uno R3

Microcontroller component where all commands from the application are processed into action on other hardware. The Arduino Uno can be powered via a USB connection or by an external power supply.

\section{Ic L293d Motor Driver}

Ic L293d Motor Driver, which functions to control the direction of rotation and speed of a DC motor or stepper motor. Able to output voltage for DC motors and stepper motors of 50 volts.

\section{Motor Dc}

A DC motor is a type of electric motor that works using a DC voltage source. DC motor, or direct current motor, as the name implies, uses direct current and indirect / directunidirectional. DC motors are used in special applications where high starting torque or constant acceleration is required for a wide speed range.

\section{Servo Motor}

A servo motor is a device or rotary actuator (motor) designed with closed-loop feedback (servo) control system so that it can be set up or adjusted to determine and ensure the angular position of the motor output shaft.

\section{Wireless Ps2 Receiver}

Serves as a receiver for input data sent from the PS 2 joystick (Transmitter).

\section{Joystick Ps2}

Functioning as a controller of the ship's trash-collecting robot in the river.

\section{Smartphone}

Serves as a display to display the results of the camera connected via wifi.

\section{Camera}

As a medium to see the trash around the ship robot.

Implementation of river garbage collection vessel robot

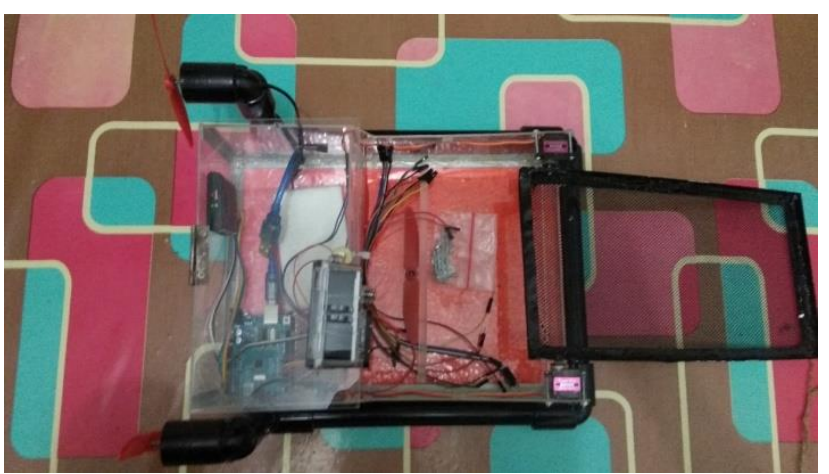

Fig. 3. Implementation of a garbage collection vessel robot in a river

\section{System Testing}

System testing of the Joystick ps 2, Ps 2 Receiver, and Arduino Uno on the trash collection ship robot system using the Arduino Uno microcontroller with an Android smartphone based joystick controller PS 2 can be done with the following steps:

1. First, turn on the trash collecting boat robot in the river.

2. After that, the trash pick-up ship robot system using an Arduino Uno microcontroller with a joystick controller PS 2 based on an Android smartphone will turn on like the supporting devices, namely Arduino Uno, Motor Relay Driver, Dc Motor, Servo Motor, Ps 2 Receiver.

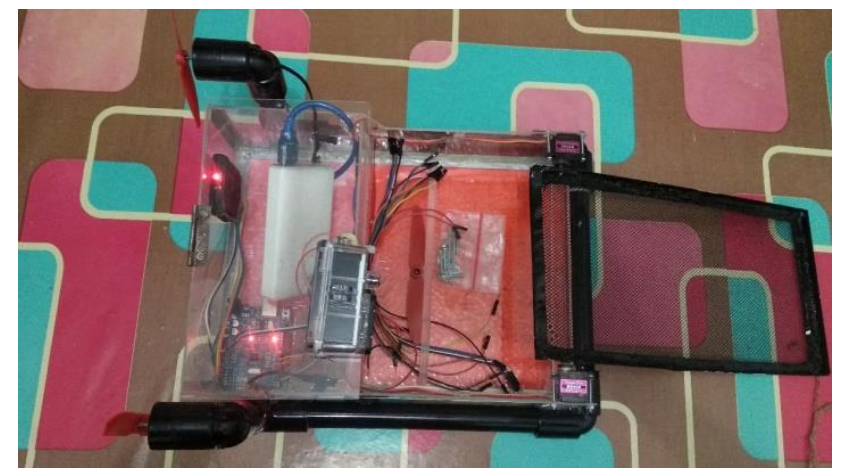

Fig.4. System Devices Turns on

3. Turn on the joystick ps 2 as the robot controller for the garbage collection boat in the river.

4. Connect the ps 2 joystick with the ps 2 wireless receiver so that the Arduino Uno process will run commands from the ps 2 joysticks.

5. Turn on the camera as a medium to see trash in the river that is connected to an android smartphone. 
6. Then prepare the Android Smartphone and open the Camera Application and turn on the Smartphone wifi and connect the smartphone to the camera, which will be used as a display to view trash.

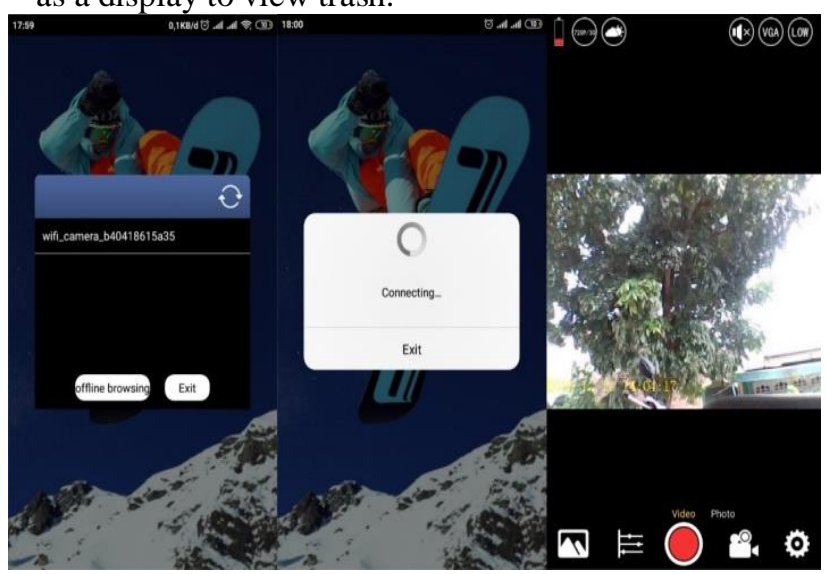

Fig. 5. Turn on Wifi Smartphone and Open the Camera Application

7. After everything is connected, then we test the buttons on the PS 2 joystick whether it goes well or not.

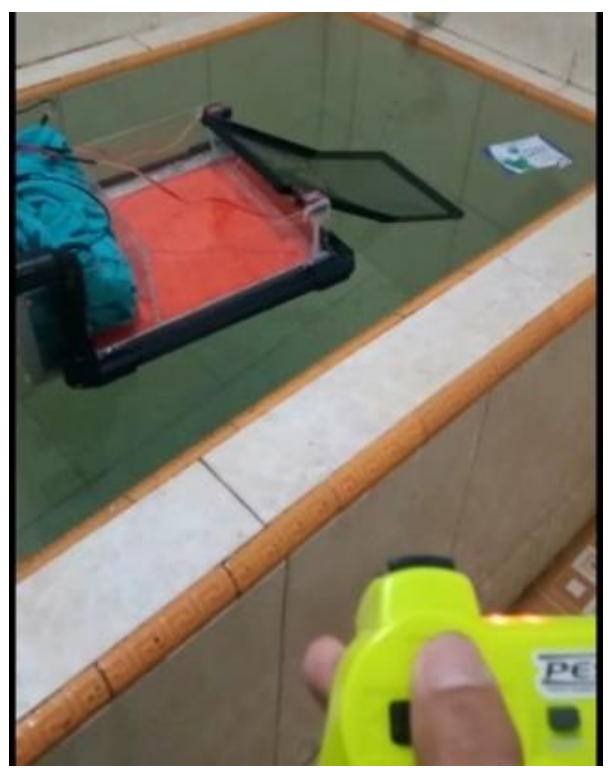

Figure. 6. Button Test

Testing Distance of Ps 2 Wireless Receiver Connectivity

Tests were carried out to find out to what extent the ps2 Wireless joystick transmitter can send data to the Ps2 Wireless Receiver, which will be written on the Arduino Uno microcontroller.
Table 2. Testing the connectivity of the Wireless Ps2 Receiver

\begin{tabular}{|l|l|l|}
\hline Distance & $\begin{array}{l}\text { There is a } \\
\text { Barrier }\end{array}$ & $\begin{array}{l}\text { Tanpa } \\
\text { Without } \\
\text { Barriers }\end{array}$ \\
\hline 1 Meter & Detected & Detected \\
\hline 2 Meter & Detected & Detected \\
\hline 3 Meter & Detected & Detected \\
\hline 4 Meter & Detected & Detected \\
\hline 5 Meter & Detected & Detected \\
\hline 7 Meter & Detected & Detected \\
\hline 10 Meter & Detected & Detected \\
\hline 15 Meter & $\begin{array}{l}\text { Not } \\
\text { detected }\end{array}$ & Not detected \\
\hline
\end{tabular}

The results of the connectivity test above indicated that the Ps2 Wireless Receiver's range reached 10 meters.

Testing Tools

Table 3. Testing Motor Dc

\begin{tabular}{|l|l|l|l|}
\hline $\begin{array}{l}\text { Trial } \\
\text { Numbe }\end{array}$ & $\begin{array}{l}\text { Type of } \\
\text { Testing }\end{array}$ & $\begin{array}{l}\text { Which is } \\
\text { expected }\end{array}$ & Result \\
\hline 1 & Move forward & $\begin{array}{l}\text { Tools can } \\
\text { move } \\
\text { forward }\end{array}$ & Accepted \\
\hline 2 & $\begin{array}{l}\text { Moving } \\
\text { backward }\end{array}$ & $\begin{array}{l}\text { The tool } \\
\text { can move } \\
\text { backward }\end{array}$ & Accepted \\
\hline 3 & $\begin{array}{l}\text { Move Turn } \\
\text { Left }\end{array}$ & $\begin{array}{l}\text { The tool } \\
\text { can turn } \\
\text { left }\end{array}$ & Accepted \\
\hline 4 & $\begin{array}{l}\text { Move Turn } \\
\text { Right }\end{array}$ & $\begin{array}{l}\text { The tool } \\
\text { can turn } \\
\text { right }\end{array}$ & Accepted \\
\hline
\end{tabular}

Table 4. Servo Motor Testing

\begin{tabular}{|l|l|l|l|}
\hline $\begin{array}{l}\text { Trial } \\
\text { Number }\end{array}$ & $\begin{array}{l}\text { Type of } \\
\text { Testing }\end{array}$ & $\begin{array}{l}\text { Which is } \\
\text { expected }\end{array}$ & Result \\
\hline 1 & $\begin{array}{l}\text { Litter bottle } \\
\text { caps }\end{array}$ & $\begin{array}{l}\text { The tool } \\
\text { can lift } \\
\text { plastic } \\
\text { waste }\end{array}$ & Accepted \\
\hline 2 & $\begin{array}{l}\text { Garbage } \\
\text { Cover Gallons }\end{array}$ & $\begin{array}{l}\text { The tool } \\
\text { can lift } \\
\text { plastic } \\
\text { waste }\end{array}$ & Accepted \\
\hline 3 & $\begin{array}{l}\text { Glass Drink } \\
\text { Trash }\end{array}$ & $\begin{array}{l}\text { The tool } \\
\text { can lift } \\
\text { plastic } \\
\text { waste }\end{array}$ & Accepted \\
\hline
\end{tabular}


Table 5. Camera Testing

\begin{tabular}{|l|l|l|l|}
\hline $\begin{array}{l}\text { Trial } \\
\text { Number }\end{array}$ & $\begin{array}{l}\text { Type of } \\
\text { Testing }\end{array}$ & $\begin{array}{l}\text { Which is } \\
\text { expected }\end{array}$ & Result \\
\hline 1 & $\begin{array}{l}\text { Camera } \\
\text { Connection }\end{array}$ & $\begin{array}{l}\text { Camera } \\
\text { Connected } \\
\text { to a } \\
\text { smartphone }\end{array}$ & Accepted \\
\hline 2 & Camera & $\begin{array}{l}\text { The } \\
\text { camera can } \\
\text { see the } \\
\text { trash } \\
\text { around the } \\
\text { ship robot }\end{array}$ & Accepted \\
\hline
\end{tabular}

\section{CONCLUSIONS}

Based on the results of the analysis, design, and implementation that have been done. Then some conclusions can be drawn, including the following: This ship robot prototype can pick up trash in the river using a ps 2 joystick where the ps 2 joysticks will be connected via a ps2 wireless receiver which is used as control of a ship with the command to move forward, move backward, turn left, turn right and pick up the trash. The only trash that can be taken by the ship robot prototype is 200 grams of garbage, such as drink bottle caps and gallon caps. This ship robot prototype is controlled by a PS 2 joystick with a connection distance between the joystick and wireless receiver of only 10 meters, and it is used to pick up trash with a river width of 10 meters and pick up trash that is on the banks of the river so that it can reduce waste buildup and reduce water pollution in the river. . By utilizing existing technology, one of which is the use of a joystick as a control for a ship/trash boat robot in a river, an Arduino Uno microcontroller as hardware to process the system input/output and wireless ps 2 as a link between the Joystick ps 2 and Arduino Uno.

\section{REFERENCES}

[1] M. R. Y. Saputra, W. W. Winarno, H. Henderi, and S. Shaddiq, Evaluation of Maturity Level of the Electronic based Government System in the Department of Industry and Commerce of Banjar Regency, J. Robot. Control, 1(5) (2020) 156-161.

[2] A. Ma'Arif, Iswanto, N. M. Raharja, P. A. Rosyady, A. R. C. Baswara, and A. A. Nuryono, Control of DC Motor Using Proportional Integral Derivative (PID): Arduino Hardware Implementation, in Proceeding 2020 2nd International Conference on Industrial Electrical and Electronics, ICIEE 2020, (2020) 74-78.

[3] W. A. Oktaviani, T. Barlian, Y. Apriani, and N. Syarif, Continuous Power Flow and Time Domain Analysis for Assessing Voltage Stability, J. Robot. Control, 1 (6) (2020) 191-198.

[4] A. Ma'arif, A. A. Nuryono, and Iswanto, Vision-Based Line following Robot in Webots, in Proceeding - 1st FORTEI-International Conference on Electrical Engineering, FORTEI-ICEE 2020, (2020) $24-28$.

[5] D. J. Suroso, M. Arifin, and P. Cherntanomwong, Distance-based Indoor Localization using Empirical Path Loss Model and RSSI in Wireless Sensor Networks, J. Robot. Control, 1 (6) (2020) 199-207.

[6] Iswanto, P. Megantoro, B. A. Pramudita, and H. A. Winarno, Wi-fi Communication Methods for Internet of Things-based Sensor
Telemetry with a Visual Basic-based User Interface, in 2020 7th International Conference on Information Technology, Computer, and Electrical Engineering (ICITACEE), (2020) 263-266.

[7] A. N. Ogbolu and S. Sukidjo, "Artificial Intelligence Vs. My Future Job: Perceptions of Asian Undergraduates," J. Robot. Control, vol. 1, no. 6, pp. 208-212, 2020.

[8] I. Iswanto, P. Megantoro, and N. M. Raharja, Development of Formalin Tester Device for Food Using Microcontroller AT89S51, Proceeding Electr. Eng. Comput. Sci. Informatics, 7 (7 -10) (2020).

[9] S. P. Humaira, I. Nursuprianah, and D. Darwan, Forecasting of The Number of Schizophrenia Disorder by using The Box-Jenkins of Time Series Analysis, J. Robot. Control, 1 (6) (2020) 213-219.

[10] Iswanto and P. Megantoro, Detection of Hypoxic Symptoms System Based on Oxygen Saturation and Heart Rate Using Arduino Based Fuzzy Method, in Proceeding - 2020 2nd International Conference on Industrial Electrical and Electronics, ICIEE 2020, (2020) 107-111.

[11] E. Safwani, A. Firdausi, and G. Hakim, Tower Planning And Arrangements Mobile Telecommunication District Central Aceh With Methode Fuzzy Clustering, J. Robot. Control, 2(1) (2021) 7-11.

[12] Iswanto, M. S. Masnawan, N. M. Raharja, and A. Ma'Arif, Infusion Liquid Level Detection Tool Using IR Sensors and Photodiode Based on Microcontroller, in Proceeding - 2020 2nd International Conference on Industrial Electrical and Electronics, ICIEE 2020, (2020) 70-73.

[13] H. F. AL-Qrimli, L. D'souza, and O. D. Hussein, "An Innovative Approach to a Hybrid Quadrotor Design," J. Robot. Control, 2 (1) (2021) 19-23.

[14] Iswanto, P. Megantoro, and B. A. Pramudita, IoT-based weather station with python user interface for measurement technique of educational purpose, in AIP Conference Proceedings, 2296 (2020).

[15] R. Alayi, H. Harasii, and H. Pourderogar, Modeling and optimization of photovoltaic cells with GA algorithm, J. Robot. Control, 2 (1) (2021) 35-41.

[16] Iswanto, P. Megantoro, and A. Ma'Arif, Nutrient Film Technique for Automatic Hydroponic System Based on Arduino, in Proceeding 2020 2nd International Conference on Industrial Electrical and Electronics, ICIEE 2020, (2020) 84-86.

[17] I. Ahmad, M. S. Niazy, R. A. Ziar, and S. Khan, Survey on IoT: Security Threats and Applications, J. Robot. Control, 2 (1)(2021) 4246.

[18] Hariyadi, P. Mutira, P. T. Nguyen, I. Iswanto, and D. Sudrajat, Traveling Salesman Problem Solution using Genetic Algorithm, J. Crit. Rev., 7 (1) (2020) 56-61.

[19] A. Latif, A. Z. Arfianto, J. E. Poetro, T. N. Phong, and E. T.Helmy, Temperature Monitoring System for Baby Incubator Based on Visual Basic, J. Robot. Control, 2 ( 1) (2021) 47-50.

[20] A. A. Nuryono, A. Ma'arif, and I. Iswanto, Comparative analysis of path-finding algorithm on unrestricted virtual object movable for augmented reality, Int. J. Sci. Technol. Res., 9(1) (2020) 160-165.

[21] M. Fadilurrahman, R. Ramadhani, T. Kurniawan, M. Misnasanti, and S. Shaddiq, Systematic Literature Review of Disruption Era in Indonesia: The Resistance of Industrial Revolution 4.0, J. Robot. Control, 2 (1) (2021) 51-59.

[22] S. Sriyanto, P. T. Nguyen, B. A. H. Siboro, I. Iswanto, and R. Rahim, Recognition of vehicle plates using template matching method, J. Crit. Rev., 7 (1) (2020) 86-90.

[23] M. Safitri, H. Da Fonseca, and E. Loniza, Short Text Message-Based Infusion Fluid Level Monitoring System, J. Robot. Control, 2 (2) (2021) 60-64.

[24] I. Iswanto and A. Ma'arif, Robust Integral State Feedback Using Coefficient Diagram in Magnetic Levitation System, IEEE Access, 8 (2020) 57003-57011,

[25] Irawan, Y., \& Wahyuni, R. Electronic Equipment Control System for Households by using Android Based on IoT (Internet of Things). In Journal Of Physics: Conference Series 1783(1) (2021).

[26] R. Ramadhani, E-Marketing of Village Tourism Development Strategy (Case Study in the Tourist Village Puncak Sosok), J. Robot. Control, 2(2) (2021) 72-77.

[27] Triwiyanto, B. G. Iranto, I. Dewa Gede Hari Wisana, H. G. Ariswati, M. P. A. T. Putra, and I. Iswanto, A modeling of the extended kalman 
filter to improve accuracy in elbow joint angle estimation, J. Crit. Rev., 7(12) (2020) 886-892.

[28] A. Hayani, E. A. Sari, and S. Sukiman, Artificial Intelligence Librarian as Promotion of IAIN Lhokseumawe Library in the Revolutionary Era 4.0, J. Robot. Control, 2(2) (2021) 88-93.

[29] Iswanto and N. Maharani Raharja, Standard Distance Detector Tool for TV users based on Fuzzy Decision Tree, IOP Conf. Ser. Mater. Sci. Eng., 851(1) (2020) 012026.

[30] M. V. S. Rao and M. Shivakumar, IR Based Auto-Recharging System for Autonomous Mobile Robot, Journal of Robotics and Control (JRC), 2(4) (2021) 244-251.

[31] D. A. Prasetya, P. T. Nguyen, R. Faizullin, I. Iswanto, and E. F. Armay, Resolving the shortest path problem using the haversine algorithm, J. Crit. Rev., 7(1) (2020) 62-64.

[32] R. Wahyuni, A. Rickyta, U. Rahmalisa, and Y. Irawan, Home Security Alarm Using Wemos D1 And HC-SR501 Sensor Based Telegram Notification, J. Robot. Control, 2(3) (2021) 200-204.

[33] Iswanto, N. M. Raharja, A. Ma'arif, Y. Ramadhan, and P. A. Rosyady, Pole Placement Based State Feedback for DC Motor Position Control, in Journal of Physics: Conference Series, 1783(1) (2021).

[34] Irawan, Y., Linarta, A., \& Febriani, A.. Smart Home Light-Based Service Oriented Architecture and IoT. In Journal of Physics: Conference Series 1845(1) (2021) 012070). IOP Publishing.

[35] U. Rahmalisa, A. Febriani, and Y. Irawan, Detector Leakage Gas Lpg Based On Telegram Notification Using Wemos D1 and Mq-6 Sensor, J. Robot. Control, 2 (4) (2021) 287-291.

[36] R. Wahyuni, J. T. Sentana, M. Muhardi, and Y. Irawan, Water Level Control Monitoring Based On Arduino Uno R3 Atmega 238p Using Lm0161 LCD at STMIK Hang Tuah Pekanbaru, J. Robot. Control, 2(4) (2021) 265-269.

[37] Beltran Jr, A., Dizon, K. J., Nones, K., Salanguit, R. L., Santos, J. B., \& Santos, J. R. Arduino-based Disaster Management System. Journal of Robotics and Control (JRC), 2(1) (2021)24-28.

[38] Wijaya, N. H., Ibrahim, M., Shahu, N., \& Sattar, M. U. (2020). Arduino-based Digital Advanced Audiometer. Journal of Robotics and Control (JRC), 2(2), 83-87.

[39] R. M. Sari, E. Sabna, R. Wahyuni, and Y. Irawan, Implementation of Open and Close a Housing Gate Portal Using RFID Card, J. Robot. Control, 2(5) (2021) 363-367.

[40] J. Susilo, A. Febriani, U. Rahmalisa, and Y. Irawan, Car Parking Distance Controller Using Ultrasonic Sensors Based On Arduino Uno, J. Robot. Control, 2(5) (2021) 353-356.
[41] Loniza, E., Dhamayanti, D. C., \& Safitri, M. Dehydration level detector through human urine with LED and LDR. Journal of Robotics and Control (JRC), 2(3) (2021) 140-144.

[42] S. Purwanti, A. Febriani, M. Mardeni, and Y. Irawan, Temperature Monitoring System for Egg Incubators Using Raspberry Pi3 Based on Internet of Things (IoT), J. Robot. Control, 2(5) (2021).

[43] Handaya, D., \& Fauziah, R. Proportional-Integral-Derivative and Linear Quadratic Regulator Control of Direct Current Motor Position using Multi-Turn Based on LabView. Journal of Robotics and Control (JRC), 2(4) (2021) 332-336

[44] S. Sinha, U. Srivastava, V. Dhiman, A. P.S, and S. Mishra, Performance assessment of Deep Learning procedures on Malaria dataset, Journal of Robotics and Control (JRC), 2 (1) (2021) 12-18.

[45] K. Khairunisa, M. Mardeni, and Y. Irawan, Smart Aquarium Design Using Raspberry Pi and Android Based, J. Robot. Control, 2 (5) (2021) 368-372.

[46] Y. Irawan, Moving Load Robot Using Wifi Network and Android Based, J. Robot. Control, 2 (3) (2021) 217-220.

[47] Z. Saleh and Y. Apriani, Analysis of Performance of Permanent Magnet Generator Fluks Axial 1 Phasa with Variation Load, J. Robot. Control, 2(2), (2021) 98-102.

[48] D. O. Oyewola and A. F. Augustine, Predicting Impact of COVID-19 on Crude Oil Price Image with Directed Acyclic Graph Deep Convolution Neural Network, J. Robot. Control, 2 (2) (2021) 103109.

[49] Y. Irawan, H. Fonda, E. Sabna, and A. Febriani, Intelligent quality control of shrimp aquaculture based on real-time system and IoT using a mobile device, Int. J. Eng. Trends Technol., 69 (4) (2021) 49-56, doi: 10.14445/22315381/IJETT-V69I4P208.

[50] T. P. Tunggal, M. Arrosyid, G. De Brito, S. A. Maseleno, and O. Tanane, The Design of X-Ray Film Reader with Film Presence Detector, J. Robot. Control, 2 (2) (2021) 110-114.

[51] X. Zhu and B. He, Underactuated Rehabilitation Robotics for Hand Function, J. Robot. Control, 2(5) (2021) 337-341.

[52] S. Widadi, S. A. B. Munir, N. Shahu, I. Ahmad, and I. Al Barazanchi, Automatic Wireless Nurse Caller, J. Robot. Control, 2(5) (2021) 380384.

[53] Devis, Y., Irawan, Y., Zoromi, F., \& Amartha, M. R. Monitoring System of Heart Rate, Temperature, and Infusion in Patients Based on Microcontroller (Arduino Uno). In Journal of Physics: Conference Series 1845(1) (2021) 012069. IOP Publishing.

[54] R. Kristiyono and W. Wiyono, Autotuning Fuzzy PID Controller for Speed Control of BLDC Motor, J. Robot. Control, 2 (5) (2021). 